Tropical Journal of Pharmaceutical Research March 2020; 19 (3): 617-622

ISSN: $1596-5996$ (print); 1596-9827 (electronic)

(C) Pharmacotherapy Group, Faculty of Pharmacy, University of Benin, Benin City, 300001 Nigeria.

Original Research Article

http://dx.doi.org/10.4314/tjpr.v19i3.23

\title{
Evaluation of 90-day subchronic oral toxicity of aqueous extract of Gmelina arborea Roxb (Verbenaceae) leaves in Wistar rats
}

\author{
Razack Osseni1-3*, Azonbakin Simon², Diallo Aboudoulatif ${ }^{4}$, Habib Ganfon ${ }^{5}$, \\ Adjagba Marius ${ }^{2}$, Fagbemi Kaossarath ${ }^{2}$, Sanni Sekossounon ${ }^{3}$, Bonaventure \\ Awede $^{1}$, Bigot André ${ }^{3}$, Darboux Raphaël' ${ }^{2}$, Lalèyè Anatole ${ }^{2}$ \\ ${ }^{1}$ Unité de Formation et Recherche en Physiologie, ${ }^{2}$ Unité de Formation et Recherche en Biologie Humaine. ${ }^{3}$ Unité de formation \\ et de Recherche en Immunologie, Faculté des Sciences de la Santé, Université d'Abomey-Calavi, Bénin, ${ }^{4}$ Département de \\ Toxicologie, Faculté Mixte de Médecine et de Pharmacie, Université de Lomé, Togo, ${ }^{5}$ Laboratoire de Pharmacognosie et de \\ Phytothérapie, Faculté des Sciences de la Santé, Université d'Abomey-Calavi, Bénin
}

*For correspondence: Email: abdourazackosseni@ymail.com; Tel: +229 96510075

Sent for review:

Revised accepted: 15 July 2019

\begin{abstract}
Purpose: To evaluate the 90 day sub-chronic toxicity of aqueous extract of Gmelina arborea leaves in Wistar rats.

Methods: Rats were submitted to repeated daily oral administration of extract (250, 62.5 and 15.62 $\mathrm{mg} / \mathrm{kg}$ ) of Gmelina arborea leaves. The control groups were given distilled water and the rats were monitored for any toxicity symptoms as well as body and organs weights, water and food intake changes. The biochemical, haematological and histolopathological parameters were analysed.

Results: The 90 days administration of the aqueous extract did not produce any toxicity signs or mortality. In addition, no significant alteration in water or food intake by the rats was observed. Although there were no changes in the body weights, significant decrease in the weight of the kidneys of the rats was observed at $250 \mathrm{mg} / \mathrm{kg}$. Biological parameters as well as the histopathology of liver and kidneys were not significantly affected. Significant decreases were noted in glucose level at the three dose levels. In addition, significant difference in the levels of transaminases, glucose and platelets were observed.

Conclusion: The 90-days subchronic toxicity test on Gmelina arborea did not produce any toxic effects. This confirms the safety of the plant leaves by traditional medicine practitioners.
\end{abstract}

Keywords: Gmelina arborea, Subchronic toxicity, Wistars rats, Biological parameters

\begin{abstract}
This is an Open Access article that uses a fund-ing model which does not charge readers or their institutions for access and distributed under the terms of the Creative Commons Attribution License (http://creativecommons.org/licenses/by/4.0) and the Budapest Open Access Initiative (http://www.budapestopenaccessinitiative.org/read), which permit unrestricted use, distribution, and reproduction in any medium, provided the original work is properly credited.
\end{abstract}

Tropical Journal of Pharmaceutical Research is indexed by Science Citation Index (SciSearch), Scopus, International Pharmaceutical Abstract, Chemical Abstracts, Embase, Index Copernicus, EBSCO, African Index Medicus, JournalSeek, Journal Citation Reports/Science Edition, Directory of Open Access Journals (DOAJ), African Journal Online, Bioline International, Open-J-Gate and Pharmacy Abstracts

\section{INTRODUCTION}

Although the World Health Organization recommended that toxicity investigations is vital in the use of herbal medicines for treating many ailments, little attention is often paid to the longterm safety of the herbs by many traditional healers [1]. Thus, only limited data are available about the safety of most commonly used medicinal plants [2]. Gmelina arborea is a plant 
largely used for the management of many diseases. The plant is known to possess many pharmacological activities such as antimicrobial [3], antioxidant [4], anthelmintic [5], anti-diabetic [6] antihypertensive [7] and cardioprotective [8]. Previous studies have reported the toxicity profile $[9,10,11]$ and cytotoxic effect $[12,13,14]$. In traditional medicine, the leaves of $G$. arborea are often used to manage chronic ailments that include high blood pressure and diabetes. While in vivo toxicological data are available on the stem bark $[10,11,15,16]$, there are no similar data on the 90-days subchronic toxicity of the leaves.

Therefore, the purpose of this study was to assess the 90-daysubchronic toxicity of the aqueous extract of $G$. arborea leaves in Wistar rats.

\section{EXPERIMENTAL}

\section{Preparation of extract}

Leaves of G. arborea were harvested at Abomey-Calavi near Cotonou in the south of Benin republic. The plant specimen was identified and authenticate by a taxonomist and the sample was deposited in a Herbarium Center in Togo (voucher no. AA6337(GA). The leaves were washed and immediately air-dried for 10 days at $20{ }^{\circ} \mathrm{C}$ and then ground into powder. Some of the powder $(150 \mathrm{~g})$ was mixed with $500 \mathrm{ml}$ of distilled water and extracted at $80{ }^{\circ} \mathrm{C}$ for 30 minutes. The decoction obtained was filtered and the resulting filtrate was evaporated using an evaporate rotator over a water-bath at $60{ }^{\circ} \mathrm{C}$. The dried residual extract was kept airtight and refrigerated.

\section{Animals}

Wistar albino rats $(40$, with mean weight of $180 \mathrm{~g}$ $\pm 20 \mathrm{~g}$ ) were acclimatized to standard laboratory environment including $25{ }^{\circ} \mathrm{C}, 12 \mathrm{~h}$ of dark and light cycle. They were kept five per cage and by sex and the animals were treated in line with the guidelines of the United States National Institute of Health for Laboratory Animal Care [17].

\section{Design of subchronicoral toxicity test}

Each of three groups of 10 rats (randomly assigned 5 males and 5 females) were administered $15.62 \mathrm{mg} / \mathrm{kg}, 62.5 \mathrm{mg} / \mathrm{kg}$ or 250 $\mathrm{mg} / \mathrm{kg}$ of the aqueous extract of $\mathrm{G}$. arborea orally for 90 days in line with the OECD 408 directive [18]. A fourth group of rats that served as the control group received distilled water. Before and after exposure to the extract, the animals were observed for any sign of toxicity such as changes in the skin, eyes and fur colour, behavioural patterns and breathing. The body weight and food intake were measured once every week. At the end, blood samples were collected in appropriate tubes after anesthetising the animals using intraperitoneal injection of thiopental. Biochemical and haematological parameters were evaluated.

The biochemical parameters included glucose, urea, creatinine, total cholesterol, aspartate aminotransferase (ASAT), alanine aminotransferase (ALAT), total proteins, and ions (sodium, potassium, chloride). A complete hemogram analysis was also performed. All rats were euthanized by lethal dose of thiopental and the spleens, lungs, livers, hearts, and kidneys of three rats per group were removed, rinsed with distilled water.

Then they were weighed and meticulously observed for any macroscopic abnormality before being fixed in a solution of $10 \%$ formalin. Then histopathological slides of kidney and liver were evaluated by a hispathologist.

\section{Statistical analysis}

GraphPad Prism Version 6 was used for the statistical analyses. Data are expressed as means \pm standard error of mean (SEM). The student' $T$ test was used to compare body weights, relative organ weight and food intake values. Data for the biological parameters were analyzed by one-way analysis of variance followed by Dunett post hoc. At $95 \%$ confidence interval, $p<0.05$ were considered significant.

\section{RESULTS}

Throughout the subchronic oral administration of the aqueous extract of $G$. arborea leaves, none of the rats died. In addition, no remarkable changes were recorded in the general behavior or other physiological activities in treated rats when compared to the control group. They both appeared healthy up to the end the study except that scratching of their bodies was observed with treated animals after administration of $250 \mathrm{mg} / \mathrm{kg}$ of the extract from day 73 .

\section{Effect of extract on body weight}

The body weights of the treated rats remain significantly unchanged (Figure 1) although there was slight decrease in the weights of the male rats during the first month.

However, significant changes were observed in food intake by the rats (Figure 2). While the food 
intake by the control rats progressively increased over a three months period, food intake by the treated rats either decreased or maintained.
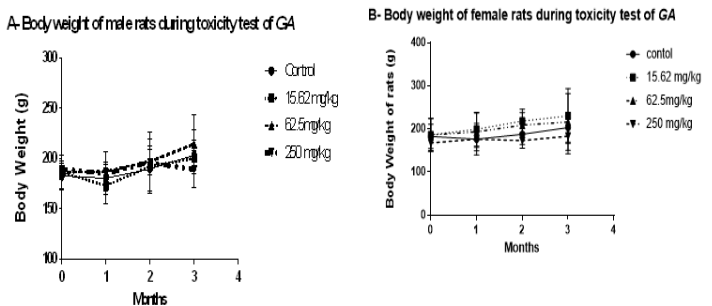

Figure 1: Body weight of rats following subchronic toxicity test

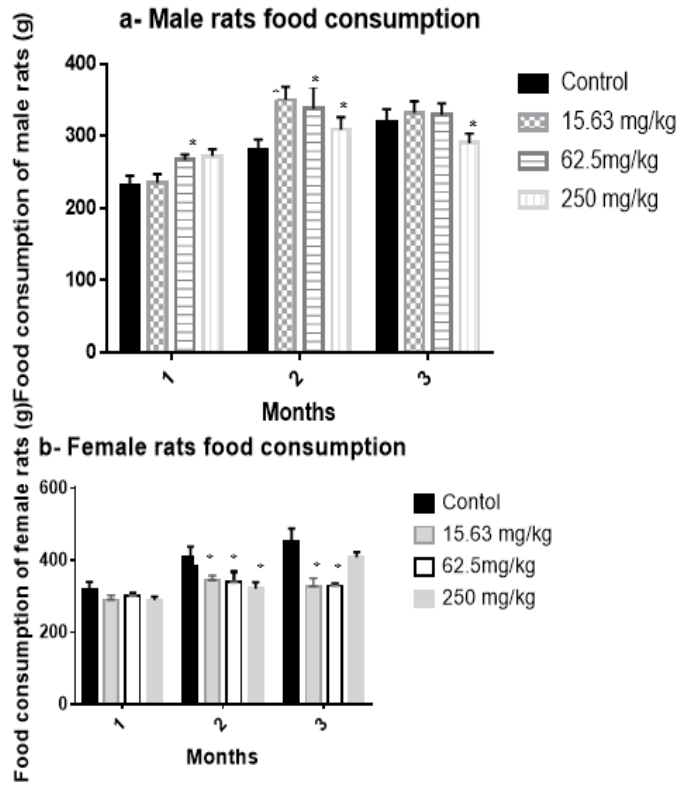

Figure 2: Rats food intake in subchronic toxicity test

There were no significant differences in the relative organ weights of the treated compared to the control rats. However, a slight decrease of the liver weight was observed in female rats (Table 1).

\section{Effects of extract on biological parameters}

In many cases, the biochemical parameters of the treated rats were not significantly different from those of the control rats. However, the extract induced a significant decrease in glucose level in both male and female rats. Moreover, an increase in transaminases (ASAT) level was observed at the doses of 62.5 and $250 \mathrm{mg} / \mathrm{kg}$ in male rats (Table 2 ).

The hematological parameters were marked by significant increase in platelet levels (Table 3 ) in the two genders of rats. Slight changes were also observed in inmonocytes counts while all the other values were not affected.

\section{Effects on tissues histology}

The histopathological photomicrograph of both liver and kidney of the rats showed no abnormality (Figure 3). Hepatic lobules showed normal architecture of hepatocytes arranged radially around the centro-lobular vein. All treated rats conserved their normal liver architecture. The kidneys also showed normal renal cortex, glomeruli (G) and tubules (t). Treated rats conserved their kidney normal architecture.
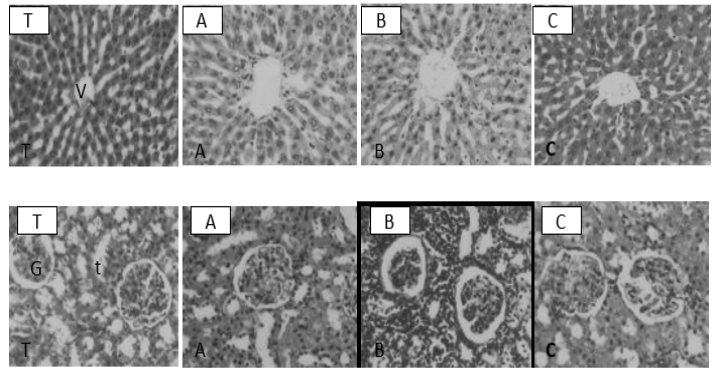

Figure 3: Histopathological photomicrograph of rat liver (top) and kidney (bottom) treated with Gmelina arborea extract (Hematoxylin Eosin $400 \mathrm{x}$ ). Control rat (T), (A: $15.62 \mathrm{mg} / \mathrm{kg}$; B: $62.5 \mathrm{mg} / \mathrm{kg}$; C: $250 \mathrm{mg} / \mathrm{kg}$ )

Table 1: Relative weights of rat organs

\begin{tabular}{llllll}
\hline Group (mg/kg) & Liver $(\mathbf{g})$ & Kidneys $\mathbf{( g )}$ & Lungs $(\mathbf{g})$ & Spleen $(\mathbf{g})$ & Heart(g) \\
\hline $\begin{array}{l}\text { Male rats } \\
\text { Control }\end{array}$ & $3.59 \pm 0.42$ & $0.60 \pm 0.07$ & $0.45 \pm 0.13$ & $0.19 \pm 0.05$ & $0.41 \pm 0.10$ \\
$\mathbf{1 5 . 6 2}$ & $3.27 \pm 0.64$ & $0.60 \pm 0.08$ & $0.41 \pm 0.18$ & $0.23 \pm 0.05$ & $0.38 \pm 0.15$ \\
$\mathbf{6 2 . 5}$ & $3.38 \pm 0.27$ & $0.66 \pm 0.08$ & $0.38 \pm 0.16$ & $0.21 \pm 0.08$ & $0.37 \pm 0.21$ \\
$\mathbf{2 5 0}$ & $3.62 \pm 0.54$ & $0.62 \pm 0.11$ & $0.39 \pm 0.16$ & $0.26 \pm 0.07$ & $0.41 \pm 0.09$ \\
Female rats & & & & & \\
$\quad$ Control & $3.09 \pm 0.39$ & $0.55 \pm 0.10$ & $0.41 \pm 0.17$ & $0.21 \pm 0.09$ & $0.39 \pm 0.19$ \\
$\mathbf{1 5 . 6 2}$ & $3.17 \pm 0.46$ & $0.58 \pm 0.23$ & $0.38 \pm 0.20$ & $0.25 \pm 0.07$ & $0.41 \pm 0.16$ \\
$\mathbf{6 2 . 5}$ & $2.88 \pm 0.22$ & $0.61 \pm 0.21$ & $0.39 \pm 0.14$ & $0.17 \pm 0.10$ & $0.38 \pm 0.14$ \\
$\mathbf{2 5 0}$ & $\mathbf{2 . 5 1 \pm 0 . 1 4}$ & $0.48 \pm 0.09$ & $0.42 \pm 0.18$ & $0.19 \pm 0.10$ & $0.40 \pm 0.10$ \\
\hline
\end{tabular}


Table 2: Biochemical parameters of rats (mean $\pm S D, n=5$ )

\begin{tabular}{|c|c|c|c|c|}
\hline Parameter & Control & $15.83 \mathrm{mg} / \mathrm{kg}$ & $62.5 \mathrm{mg} / \mathrm{kg}$ & $250 \mathrm{mg} / \mathrm{kg}$ \\
\hline \multicolumn{5}{|l|}{ Male rats } \\
\hline Glucose (g/L) & $1.06 \pm 0.20$ & $0.59 \pm 0.03^{*}$ & $0.71 \pm 0.03^{*}$ & $0.80 \pm 0.02^{*}$ \\
\hline Urea $(g / L)$ & $0.55 \pm 0.01$ & $0.58 \pm 0.02$ & $0.43 \pm 0.23$ & $0.51 \pm 0.09$ \\
\hline Creatinine (mg/L) & $2,72 \pm 1.28$ & $3,83 \pm 0.67$ & $3,94 \pm 0.42$ & $3,57 \pm 0.42$ \\
\hline ASAT (UI/L) & $126 \pm 1.21$ & $111 \pm 26.8$ & $181.5 \pm 14.54$ & $191 \pm 14.17^{*}$ \\
\hline ALAT (UI/L) & $119 \pm 28.28$ & $83 \pm 15.52^{*}$ & $93.5 \pm 10.60$ & $195.5 \pm 16.9 *$ \\
\hline Total cholesterol (g/L) & $0.62 \pm 0.07$ & $0.69 \pm 0.05$ & $0.61 \pm 0.00$ & $0.72 \pm 0.13$ \\
\hline Sodium (mEq/L) & $141.5 \pm 0.70$ & $141 \pm 0.00$ & $141 \pm 2.82$ & $140 \pm 1.00$ \\
\hline Potassium (mEq/L) & $5.2 \pm 1.55$ & $4.96 \pm 0.65$ & $5.3 \pm 0.00$ & $5.5 \pm 1.58$ \\
\hline Chloride (mEq/L) & $102.5 \pm 0.70$ & $100.66 \pm 0.57$ & $102 \pm 1.41$ & $102.33 \pm 1.15$ \\
\hline Protein $(\mathbf{g} / \mathbf{L})$ & $80 \pm 0.00$ & $75.33 \pm 2.33$ & $78 \pm 1.41$ & $72 \pm 0.00$ \\
\hline \multicolumn{5}{|l|}{ Female rats } \\
\hline Glucose (g/L) & $1.19 \pm 0.09$ & $0.90 \pm 0.03$ & $0.58 \pm 0.03^{*}$ & $0.39 \pm 0.52^{*}$ \\
\hline Urea $(g / L)$ & $0.61 \pm 0.15$ & $0.52 \pm 0.12$ & $0.59 \pm 0.18$ & $0.56 \pm 0.10$ \\
\hline Creatinine (mg/L) & $2,69 \pm 1.28$ & $3,83 \pm 0.67$ & $3,94 \pm 0.42$ & $3,57 \pm 0.42$ \\
\hline ASAT (UI/L) & $116 \pm 26$ & $145 \pm 20.8$ & $210.5 \pm 19.54^{*}$ & $261 \pm 34^{*}$ \\
\hline ALAT (UI/L) & $99 \pm 10.31$ & $123 \pm 23.2$ & $182.4 \pm 25.63^{*}$ & $213.5 \pm 34.9 *$ \\
\hline Total cholesterol (g/L) & $0.50 \pm 0.01$ & $0.61 \pm 0.05$ & $0.56 \pm 0.00$ & $0.65 \pm 0.04$ \\
\hline Sodium (mEq/L) & $140.2 \pm 0.81$ & $139 \pm 0.04$ & $140 \pm 0.85$ & $143 \pm 0.99$ \\
\hline Potassium(mEq/L) & $4.40 \pm 1.25$ & $4.86 \pm 0.55$ & $4.28 \pm 0.28$ & $5.00 \pm 0.75$ \\
\hline Chloride (mEq/L) & $105 \pm 0.15$ & $100 \pm 0.20$ & $102 \pm 1.41$ & $102.33 \pm 1.15$ \\
\hline Protein $(\mathrm{g} / \mathrm{L})$ & $75.82 \pm 0.58$ & $75 \pm 1.03$ & $72.58 \pm 0.98$ & $80 \pm 0.85$ \\
\hline
\end{tabular}

ASAT: Aspartate Amino-Transferase, ALAT: Alanine Amino Transferase. ${ }^{*} p<0.05$ : Significantly different from the control group. Values represent Means \pm SEM.

Table 3: Hematological parameters of rats (mean SD, $n=5$ )

\begin{tabular}{|c|c|c|c|c|}
\hline Parameters & Control & $15.83 \mathrm{mg} / \mathrm{kg}$ & $62.5 \mathrm{mg} / \mathrm{kg}$ & $250 \mathrm{mg} / \mathrm{kg}$ \\
\hline \multicolumn{5}{|l|}{ Male rats } \\
\hline Erythrocytes (10 $12 / L)$ & $7.32 \pm 0.35$ & $6.55 \pm 0.65$ & $7.11 \pm 0.22$ & $6.06 \pm 0.55^{*}$ \\
\hline Hemoglobin (g/dl) & $15.56 \pm 0.90$ & $14.06 \pm 1.66$ & $15.36 \pm 0.70$ & $13.3 \pm 0.95^{\star}$ \\
\hline Hematocritte (\%) & $52 \pm 2.08$ & $47 \pm 5.68$ & $50 \pm 1.73$ & $42 \pm 3.51^{*}$ \\
\hline MGV (fL) & $70 \pm 0.57$ & $72 \pm 2.64$ & $70 \pm 2.88$ & $70 \pm 1.52$ \\
\hline $\mathrm{MCH}(\mathrm{pg})$ & $21 \pm 0.57$ & $21 \pm 1.15$ & $22 \pm 0.57$ & $22 \pm 0.57$ \\
\hline $\mathrm{MCHC}(\%)$ & $30 \pm 0.57$ & $30 \pm 0.57$ & $31 \pm 1.00$ & $31 \pm 0.57$ \\
\hline Leukocytes(109/L) & $5.44 \pm 1.86$ & $6.91 \pm 2.76$ & $7.58 \pm 0.91$ & $6.16 \pm 2.47$ \\
\hline neutrophiles $\left(10^{9} / \mathrm{L}\right)$ & $0.79 \pm 0.58$ & $1.76 \pm 0.78$ & $1.64 \pm 0.89$ & $0.55 \pm 0.31$ \\
\hline Eosinophiles (10\%/L) & $0.08 \pm 0.24$ & $0.00 \pm 0.00$ & $0.02 \pm 0.00$ & $0.00 \pm 0.00$ \\
\hline Basophiles & 0.00 & 0.00 & 0.00 & 0.00 \\
\hline Lymphocytes (109/L) & $4.10 \pm 0.56$ & $4.56 \pm 0.93$ & $5.43 \pm 0.87$ & $5.48 \pm 1.01$ \\
\hline Monocytes (109/L) & $0.46 \pm 0.02$ & $0.58 \pm 0.02^{*}$ & $0.50 \pm 0.02^{*}$ & $0.12 \pm 0.02^{*}$ \\
\hline Platelets $\left(10^{3} / \mu \mathrm{L}\right)$ & $472.33 \pm 49.21$ & $624 \pm 34.87^{*}$ & $719.66 \pm 95.19 *$ & $572 \pm 30.04^{*}$ \\
\hline \multicolumn{5}{|l|}{ Female rats } \\
\hline Erythrocytes (10 $12 / L)$ & $6.31 \pm 0.25$ & $6.51 \pm 0.55$ & $6.55 \pm 0.12$ & $5.55 \pm 0.02^{*}$ \\
\hline Hemoglobin $(g / d l)$ & $13.26 \pm 0.90$ & $13.06 \pm 1.06$ & $14.20 \pm 0.90$ & $16.29 \pm 0.89$ \\
\hline Hematocritte (\%) & $46.56 \pm 2.08$ & $44.33 \pm 5.68$ & $50.00 \pm 1.73$ & $42.33 \pm 3.51$ \\
\hline MGV (fL) & $73.78 \pm 1.57$ & $72.00 \pm 2.64$ & $70.33 \pm 2.88$ & $70.33 \pm 1.52$ \\
\hline $\mathrm{MCH}(\mathrm{pg})$ & $21.66 \pm 0.57$ & $21.66 \pm 1.15$ & $21.33 \pm 0.57$ & $21.66 \pm 0.57$ \\
\hline $\operatorname{MCHC}(\%)$ & $28.82 \pm 4.32$ & $29.66 \pm 0.57$ & $31.00 \pm 1.00$ & $31.33 \pm 0.57$ \\
\hline Leukocytes(109/L) & $8.44 \pm 2.14$ & $9.56 \pm 4.27$ & $10.58 \pm 4.98$ & $9.16 \pm 4.87$ \\
\hline neutrophiles $\left(10^{9} / \mathrm{L}\right)$ & $3.05 \pm 1.06$ & $2.19 \pm 0.82$ & $2.00 \pm 0.84$ & $2.52 \pm 0.97$ \\
\hline Eosinophiles (10\%/L) & $1.00 \pm 0.00$ & $0.20 \pm 0.11^{*}$ & $0.28 \pm 0.16^{*}$ & $1.20 \pm 0.76$ \\
\hline Basophiles & 0.00 & 0.00 & 0.00 & 0.00 \\
\hline Lymphocytes (109/L) & $5.22 \pm 1.04$ & $6.30 \pm 2.82$ & $7.51 \pm 0.35$ & $4.94 \pm 1.67$ \\
\hline Monocytes $\left(10^{9} / \mathrm{L}\right)$ & $0.84 \pm 0.09$ & $0.84 \pm 0.10$ & $0.20 \pm 0.08^{*}$ & $0.50 \pm 0.12^{*}$ \\
\hline Platelets $\left(10^{3} / \mu \mathrm{L}\right)$ & $528.13 \pm 49.21$ & $851 \pm 04.27^{*}$ & $919.62 \pm 36.08^{*}$ & $798 \pm 15.24^{*}$ \\
\hline
\end{tabular}

MGV: Mean globular volume, MCH: mean concentration hemoglobin, MCHC: mean corpuscular hemoglobin concentration, ${ }^{*} p<0.05$ : Significantly different from the control group. Values represent means \pm SEM

\section{DISCUSSION}

In our knowledge, this study is the first to provide data on the 90-days subchronic toxicity of the leaves from Gmelina arborea. The aqueous extract of $G$. arborea has been found to have induced a significant decrease in glucose, increase in transaminases level and significant 
increase in the hemogram of treated rats. The leaf extract did not impact changes in the rats behavioral patterns and there were no significant differences in their relative weights in kidneys, heart, lungs and spleen when compared to the control rats in both genders $(p>0.05)$. Thus, the extract was considered non-toxic.

An earlier study [16], showed that the alcoholic extract of $G$. arborea did not result in mortality, changes in behavior or any other physiological activities in mice [16]. Our findings are also similar to other earlier reports $[10-12,15,16,20]$. The decrease in blood glucose is similar to that of previous reports $[6,21]$. Transaminases are not considered to be pathologic. Most previous studies indicated that the stem bark extract of $G$. arborea did not affect transaminases and gamma glutamyltransferase levels in treated rats as compared to untreated healthy rats. But during subchronic study of the leaves, an increase of transaminases activity was observed. All the other parameters used to assess the renal function throughout the administration of $G$. arborea extract remain unchanged. This observation indicates that the extract did not cause injuries on either liver cells, liver function or the renal function at any of the doses tested. The extract essentially had no effects on the hematological parameters (Table 4) even though the red line cells were decreased which could not be considered as pathologic. The other results revealed no gross abnormalities in white blood cells but significant increase in platelets. However, our findings suggest that $G$. arborea may stimulate thrombopoeisis [22].

Generally, a simple index to know toxicity of a substance after exposure is body weight gain of exposed animals as well as their relative organ weights [23]. Macroscopic examinations of liver and kidneys of treated rats did not show any changes in shape, size or color in comparison with control rats. This suggests that subchronic administration of $G$. arborea at the studied doses did not alter either the hepatic or the renal functions. However, in a previous study on the 28-days subacute toxicity of $G$. arborea [9], biological changes and histopathological alterations in hepatic and renal function were reported. None of the previous authors reported histopathological alterations with the stem bark of the plant.

\section{CONCLUSION}

This study indicates that the extract of the leaves of $G$. arborea is non-toxic. This finding strengthens an earlier report on the safety of the leaves of $G$. arborea as used in traditional practice. However, further studies are required to isolate the active principles in the plant.

\section{DECLARATIONS}

\section{Acknowledgement}

This work was partially funded by the "University of Abomey-Calavi of Benin" Program.

\section{Conflict of interest}

The authors declare there is no conflict of interest with any financial organization regarding the material discussed in the manuscript.

\section{Authors' contribution}

We declare that this work was done by the author(s) named in this article and all liabilities pertaining to claims relating to the content of this article will be borne by the authors. OR, DA, DR and BA conceptualized the study, data analysis and contributed in manuscript writing; AS, AM, FK and LA realized the histopathological analyses and contributed in manuscript writing, HG carried outed plant extraction, SS and BA realized the biochemical analyses. All authors read, participated in review and approved the manuscript for publication.

\section{Open Access}

This is an Open Access article that uses a funding model which does not charge readers or their institutions for access and distributed under the terms of the Creative Commons Attribution License (http://creativecommons.org/licenses/by/ 4.0) and the Budapest Open Access Initiative (http://www.budapestopenaccessinitiative.org/rea d), which permit unrestricted use, distribution, and reproduction in any medium, provided the original work is properly credited.

\section{REFERENCES}

1. WHO (World Health Organization). WHO guidelines on safety monitoring of herbal medicines in pharmacovigilance systems. 2008; Geneva

2. Gurib-Fakim A. Medicinal plants: Traditions of yesterday and drugs of tomorrow. Molecular Aspects of Medicine 2006; 27: 1-93.

3. El-Mahmood AM, Doughari JH, Kiman HS. In vitro antimicrobial activity of crude leaf and stem bark extracts of Gmelina arborea (Roxb) against some pathogenic species of Enterobacteriaceae. Afr. J. Pharm. Pharmacol 2010; 4(6): 355-61.

4. Patil SM, Kadam VJ, Ghosh R. In vitro antioxidant activities of methanolic extract stem bark of Gmelina

Trop J Pharm Res, March 2020; 19(3): 621 
arborea Roxb (Verbenaceae). Int. J. PharmTech2009;1(4): 1480-1484

5. Bhabani SN, Manas RD, Ansuman S, Suprava S. Anthelmintic and antidiabetic activities of gmelina arborea roxb. Bark extracts. In original International Journal of Sciences.2015; (2): 113-17

6. Pattanayak $P$, Parhi $P K$, Mishra SK, Khandei PK. Screening of anti-diabetic activity of bark extracts of gmelina arborea in Streptozotacin induced diabetic rats. Int. J. Pharmaceutic. Sci. Rev. Res 2011; 8(2): 130-132

7. Wansi SL, Kayem F, Siaka F, Nyadjeu P, Kamanyi A. Antioxidative and antihypertensive effects of the aqueous extract leaf of Gmelina arborea of rats fed with high sodium chloride diet. Pharmacol 2009; 2:750-762.

8. Vijay $T$, Dhana $R$, Sarumathy $K$, Palani $S$, Sakthivel $K$. Cardioprotective, antioxidant activities and Phytochemical analysis by GC-MS of Gmelina arborea (GA) in Doxorubicin-induced myocardial necrosis in Albino rats. J. Appl. Pharmaceutic Sci 20115; 198-204.

9. Osseni R, Awede B, Adjagba, Kpadonou C, Fall $M$, Laleye A, Darboux R. Acute and Subchronic Toxicity of Gmelina arborea Roxb, (Verbenaceae) in Wistar Rat. Int. J. Toxicol. Pharmacol. Res 2015; 7(2): 116-122

10. Ashalatha $M$ and Kuber S. Toxicity Study of GambhariPhalaChurna. Int. Ayurvedic Medical J 2014; 2(6):959-963.

11. Kulkarni $Y$ and Veeranianevulu A. Toxicological studies on aqueous extract of Gmelina arborea in rodents. Pharm Biol2010; 48(12):13-20.

12. Rohit S, Goli D, Kalyani D, Paras S. In vitro Cytotoxicity of Gmelina arborea roxb (Gambhari) on HL-60 Cell Lines. Res. J. Med. Plant2015; 9 (4): 194-200,

13. Mosad AG, Hussein AS, Hassan MFM, Laila AR, Mona AM, Amal MS. Antioxidant and Cytotoxic Activities of Flavonoidal Compounds from Gmelina arborea Roxb. Global J. Pharmacol 2014; 8 (1): 87-97.

14. Hossein AS, Hassan MFM, Laila AR, Mona AM, Amal MS, Mosad AG. Antioxidant and Cytotoxic Activities of Gmelina arborea ROXB. Leaves. Brit. J. Pharmaceutic. Res 2014; 4(1): 125-144,
15. Kulkarni YA, Veeranjaneyulu A. Toxicological Evaluation of the Methanol Extract of Gmelina arborea Roxb. Bark in Mice and Rats. Toxicol Int. 2012; 19(2): 125-131.doi: 10.4103/0971-6580.97203

16. Kulkarni YA, Chavan D, Shah K. Toxicity study and analgesic activity of Gmelina arborea extract and its fractions. Journal of Natural Pharmaceuticals 2013; 4(1): 71-74

17. National Institute of Health. Guide for the care and use of laboratory animals. NIH publication no. 85-23, 1985; Bethesda, USA,

18. Organization of Economic Cooperation and Development (OECD). The OECD guidelines for the testing of chemicals Test No 408: Repeated Dose 90-Day oral toxicty study in rodents. OECD (1998).

19. Atsamo AD, Nguelefack TB, Datté JY, Kamanyi A. Acute and subchronic oral toxicity assessment of the aqueous extract from the stem bark of Erythrinas enegalensis (Fabaceae) in rodents. J Ethnopharmacol 2011; 12; 134 (3):697-702.

20. Attanayake $A P$, Jayatilaka KAPW, Pathirana $C$ and Mudduwa $L K B$. Sub-chronic toxicological investigation of Gmelina arborea (verbenaceae) in healthy wistar rats. Int J Pharm Sci Res. 2013; 4(12): 4549-4554.

21. Attanayake $A P$, Jayatilaka $K A$, Pathirana $C$, Mudduwa LK. Gmelina arborea Roxb. (Family: Verbenaceae) Extract Upregulates the $\beta$-Cell Regeneration in STZ Induced Diabetic Rats. J Diabetes Res ;2016: 4513871. DOI: 10.1155/2016/4513871. Epub

22. Yakubu MT, Akanji MA, Oladiji AT. Haematological evaluation in male albinos rats following chronic administration of aqueous extract of Fadogiaagrestis Stem. Pharmacog Mag2007;3: 34-38.

23. Costa-Silva JH, Lima CR, Silva EJR, Araujo, AV, Fraga MCCA, Ribeiro e Ribiero A, Arruda AC, Lafayette, SSL, Wanderley AG. Acute and subacute Toxicity of the Carapaguianensis Aublet (Meliaceae) seed oil. J. Ethnopharmacol 2008; 116 (3) 495-500. 